CONSERVATION OF THE NATURE AND NATURAL RESOURCES IN NEPAL: TRADITIONAL VERSUS MODERN APPROACHES AND MANAGEMENT ISSUES IN PROTECTED AREAS

\author{
PURNA NATH MISHRA \\ Chairman \\ MAB National Committee, Nepal
}

Proceedings of the South and Central Asian MAB Meeting of Experts on Environmental Conservation, Management and Research, Hikkaduwa, Sri Lanka 15-18 October 2002

\begin{abstract}
Summary: Nepal, a small mountainous country very rich in flora, fauna and cultural heritage, requires an appropriate approach to balance the people's need with the conservation of the nature and natural resources. The indigenous system of sustainable conservation practice had been replaced in the 1970s by the modern National Park approach, which is highly successful in a limited area. Since the mid 1980 s, a new participatory biodiversity conservation approach was initiated in Nepal to integrate munity development with the management of the natural resources through the mobilization of the local people. The success and significant achievements of the protected area management system have been noted. Management issues in protected areas have also been highlighted with special reference to habitat encroachments for resource exploitation, settlement, poaching etc. Some important recommendations have also been incorporated in the present paper.
\end{abstract}

\title{
Introduction
}

The globally significant nature and natural resources of Nepal reflect her unique topography and bioclimatic zonations. Nepal, covering an area of $147,181 \mathrm{sq} . \mathrm{km}$, is at the southern slopes of the Central Himalayas, where two big bio-geographical realms (the Palearctic and Indo-Malayan) merge, and the major floristic provinces of Asia (the Sino - Japanese, Indian, Western and Central Asiatic, Southeast Asiatic, and African Indian desert) overlap to create unique and rich biodiversity. Although it covers only 0.03 per cent of the earth's land area, Nepal is home to more than 7,000 flowering plants, 1,000 moths, 635 butterflies, 186 fishes, 51 amphibians, 124 reptiles, 844 birds and 181 mammalian species. Several of these elements of biodiversity are rare, endangered and globally significant.

Nepal is comprised of several ethnic communities, each with its unique tradition, and cultural and socio-economic systems. Although it has a population of only 23.1 million and an annual growth rate of over 2 per cent, its overall biodiversity is highly threatened owing to the population's high dependency on natural resources. In this context, Nepal needs an appropriate approach to accelerate economic growth and to safeguard its precious nature and natural resources. 


\section{A Brief History}

Until the late nineteen fifties, Nepal was almost isolated from the rest of the world owing mainly to its rugged topography, poor transportation and communication systems. As a result, people were less dependant on the exotic and more dependant on the native natural resources. To control overexploitation of the natural resources with due respect to the ecological, socio-economic, and cultural limits, people developed a system of resource management called the indigenous system. The indigenous system worked effectively up to the 1950s, and that was the time when a few of the Terai forests were protected and managed by declaring them as royal hunting areas, which was more or less akin to the protected area status.

The country's political development in 1950 accelerated the modernization process and was instrumental in weakening the indigenous system of the natural resources conservation in Nepal.

\section{Table 1: History of Biodiversity Conservation in Nepal}

\begin{tabular}{ll}
\hline \multicolumn{1}{c}{ Period } & \multicolumn{1}{c}{ Management Practices } \\
\hline Before 1950 & $\begin{array}{l}\text { 1 Indigenous Resource Management System } \\
2 \text { As the royal hunting areas, some Terai forests } \\
\text { were managed like present protected area systems }\end{array}$ \\
& $\begin{array}{l}\text { Disruption of indigenous systems and lack of } \\
\text { appropriate legal provision for natural resources } \\
\text { conservation }\end{array}$ \\
& $\begin{array}{l}\text { Initiation of effective conservation approaches with the } \\
\text { establishment of the Protected Area System (PAS) }\end{array}$ \\
1973-mid 1980s & $\begin{array}{l}\text { Initiation of the participatory conservation approach } \\
\text { through the establishment of conservation areas to } \\
\text { integrate community development with natural } \\
\text { resources management. } \\
\text { Introduction and establishment of the Buffer Zone } \\
\text { concept. } \\
\text { Mid 1990-2000 }\end{array} \quad \begin{array}{l}\text { Introduction of the holistic and integrated conservation } \\
\text { approach by way of landscape conservation initiatives. }\end{array}$ \\
\hline
\end{tabular}

Due to the lack of an appropriate conservation policy, habitats and numbers of many wildlife species including rhinoceros, tiger, wild elephant, wild buffalo etc., became highly degraded and alarmingly declined in the space of 2 decades (1950-70). It was only in the early nineteen seventies that comparatively stronger conservation programmes were initiated by establishing protected area systems in the country. 
In addition, since the mid eighties, a highly effective local people oriented participatory conservation approach has been launched in the country, which includes the establishment of conservation areas and demarcation of buffer zones around the periphery of the protected areas. Recently, other new approaches like conservation on the basis of eco-region, and managing within a landscape has been gaining momentum in the country.

\section{Conservation Approaches}

Indigenous Conservation Approach: The indigenous system of natural resources management has existed in Nepal for centuries. The locally evolved indigenous systems are attuned to the corresponding socio-economic and ecological conditions, and have been more or less sustainable. Traditionally, the people of Nepal used simple, effective, and affordable measures to preserve their natural resources. ${ }^{1}$ These systems were based on unwritten laws and rules. Communal resources such as lands, pastures, forests, wildlife, water bodies etc were collectively managed and utilized by the local people. The indigenous method of resources conservation involved protection, utilization and restoration of communal resources, which ultimately ensured the preservation of quantity and quality. For example, collection of only dead wood, planting, pruning, and selective felling of forest trees and controlling overexploitation of pasturelands through rotational grazing, ensured continuous supply. The prevailing ban in the Trans-Himalayan region of the country ${ }^{8}$ imposed by the local community on the exploitation of natural resources throughout the year definitely minimizes their indiscriminate use and overutilization.

Until 1950, communities enjoyed autonomy in natural resource management. Communal ownership and the collective use of forest and other resources on a rotational basis formed a key management strategy among the communities. Several indigenous resource management practices existed in Nepal. Among the most popular practices were the Kipat system of the Rai and Limbu of the eastern hill, the Singho naua of the Sherpas of the Everest region, the Ritithiti of the Gurung of western Nepal, religious forest/sacred grooves of the majority of Hindus etc.

Kipat system: Kipat was communal land enjoyed by the Rai and Limbu on which the state did not levy taxes until recent decades. ${ }^{7}$ Under this system, natural resources such as lands, pastures and forest were controlled by clans and distributed in accordance with family requirements. ${ }^{7}$ These systems help communities to maintain and regulate their relationship with nature.

Singho naua: Shingo naua was a traditional forest management system of the Sherpa communities of the Khumbu region. Every Sherpa village in Khumbu, in the Mount Everest area, would appoint two local people known as Naua (literally meaning guards) to control the use of communal resources. ${ }^{1}$ The Singhonaua could hold the office for as long as 12 years. He could retained the right to inspect the 
stacks of wood in houses, demand an explanation for any unusual quantity, fine defaulter, and permit people to fell trees depending upon their needs. The fine collected was used for communal welfare.

Ritithiti: Ritithiti is customary rules and regulations that work as a moral binding force. ${ }^{4}$ Gurung communities of mid west Nepal have been controlling and managing forest and pasture resources communally through generations with the help of the traditional Ritithiti system exercised through the council of village leaders known as Mukhiya. ${ }^{4}$ Communities were collectively responsible for forest and pasture management.

\section{Royal Hunting Reserve}

Until the late fifties, in order to protect wild animals for sport hunting by the royalties, some of the large forest areas mostly in Terai were set aside as Hunting Reserve. As common people were not allowed to utilize resources of these areas and the royalties would exercise selective hunting, no doubt hunting reserves to some extent also served for the conservation purpose.

\section{Success of the Systems}

The indigenous systems guaranteed a continuous supply of natural resources by developing a mechanism of social control on the common resources. Communal ownership provided checks and balances to prevent over-harvesting by illegal means. The indigenous approach was based on equitability, communal responsibility, respect and welfare. Thus it could be viewed as a bottom up approach. ${ }^{1}$ As the local communities had the power and responsibility of protecting and managing the resources, there was active participation and cooperation, and the system was based on self-reliance. This approach of conservation is considered effective, enduring and profitable, and can be assumed to have been successful for many reasons: i) there was strong cooperation which followed the unwritten laws, ii) the forests were well preserved which in turn ensured the protection of wildlife, agricultural land, and water quality, and iii) the whole system involved no direct costs which is one of the most serious problems today.

Religious forest/ Sacred grooves: The Nepalese pattern of social life that emerged from the teachings of Hinduism and Buddhism mandates respect for nature. The people of Nepal have a tradition to protect religious forest/ sacred grooves in the name of the god, goddess and religious beliefs. On the top of a barren and denuded hill or mountain in the lower Himalayas, one can observe a patch of trees at the top and within the patch there is a shrine and temple. The people consider the grooves most sacred. Villagers do not exploit anything from grooves. Trees cannot be felled or chopped, even fallen wood is not used by villagers but restricted to temple use. Apart from the 
restriction on the use of trees, hunting is prohibited. There are hundreds of such grooves in Nepal. There are many sacred forests comparatively bigger in size than grooves (for example the Bajrabarachi temple forest in Kathmandu valley and Kalika temple forest in Baglung) in Nepal. Sacred forests / grooves are relics of natural vegetation under minimal use. They habour biodiversity representative of a region. They preserve key species and in certain cases it may preserve rare species. Thus conservation of sacred grooves is vital in saving the natural heritage of Nepal.

\section{Protective Conservation Approach}

A key concept behind the protective conservation approach is "shielding parks from outside human interference and providing a primary benefit to wild animals". This concept has defined a park as a relatively large area that is not materially altered by human exploitation or occupation, and where the highest competent authority of the country has taken steps to prevent or eliminate exploitation or occupation in the whole area (IUCN 1975). The approach was applied in Nepal in 1973. Resident people were displaced from some of the parks in order to meet the criteria of definition.

The main objective of the protective conservation approach is to protect wildlife and their habitat. Eco-tourism development is a secondary objective. Nepal has embarked upon the modern era of biodiversity conservation since 1973 . Establishment of national parks and other Protected Area Systems (PAS) has been a key conservation strategy to protect biodiversity. ${ }^{2}$ The concept of PAS in Nepal was primarily initiated for the protection of wildlife, especially endangered species. The National Park and Wildlife Conservation (NPWC) Act (1973), was a major breakthrough in conservation and protected area establishment in Nepal. The Act and its successive amendments have identified six categories of PAS, as follows:

National Park, Strict Nature Reserve (not yet established in the country), Wildlife Reserve, Hunting Reserve, Conservation Area, and Buffer Zone

Under the Act so far, 9 National Parks, 3 Wildlife Reserves, 3 Conservation Areas, 1 Hunting Reserve, 1 National Park and a Conservation Area have been established. This Act had made strong provisions to safeguard the endangered and rare biodiversity elements of the country. According to the NPWC Act 1973, 27 mammal, 9 bird, and 3 reptile species are fully protected. Nepal is a unique example of adapting the collaborative approach of PA management with strict law enforcement through deployment of the Royal Nepal Army (PPP 1999).

\section{Achievements}

- Establishment of an impressive network of Protected Areas. 


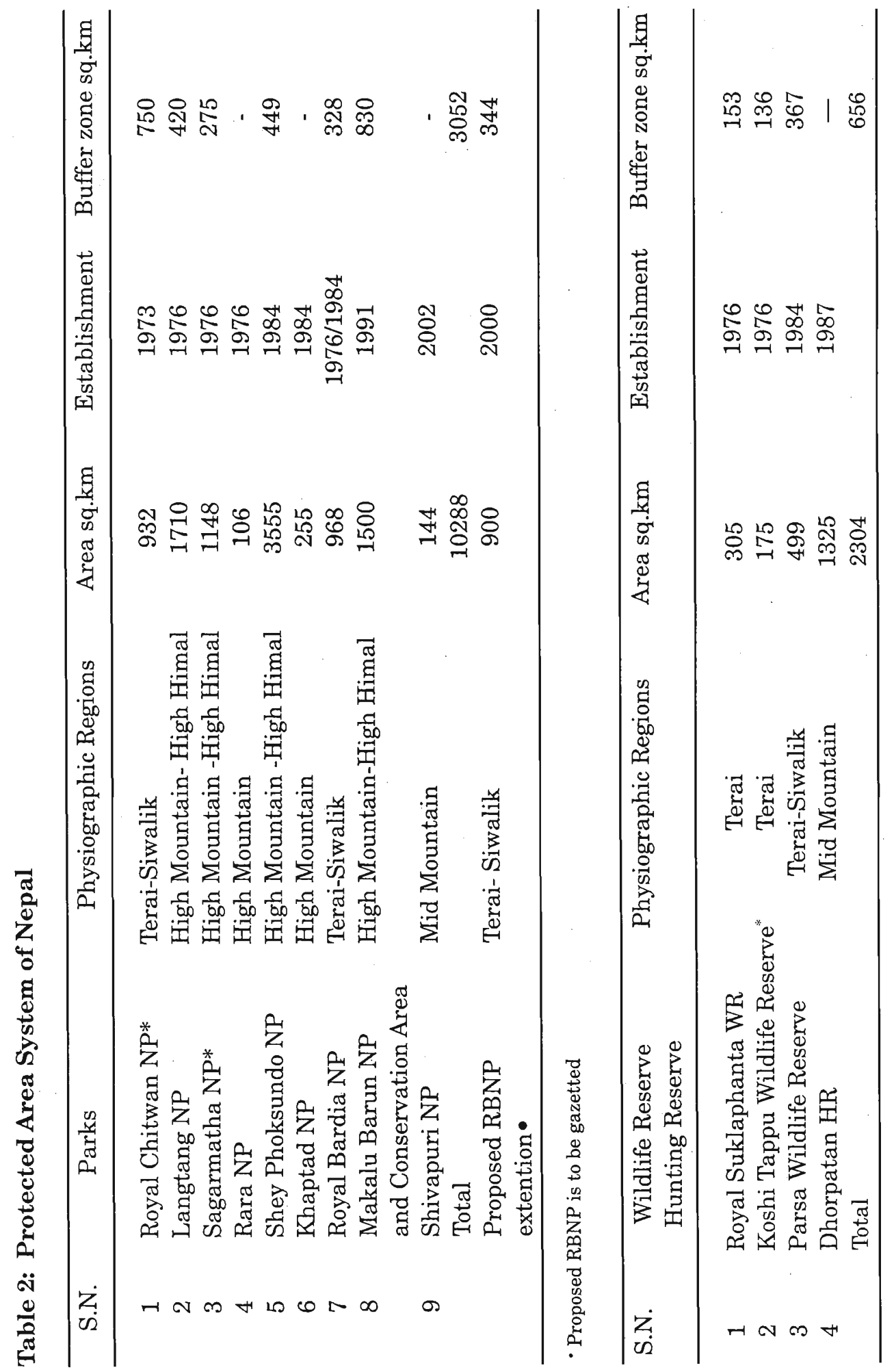




\begin{tabular}{llccc}
\hline S.N. & Conservation Area & Physiographic Regions & $\begin{array}{c}\text { Area } \\
\text { sq.km }\end{array}$ & Establishment \\
\hline 1 & Annapurna CA & Mid Mountain- High Himal & 7629 & 1992 \\
2 & Kanchanjunga CA & Mid Mountain-High Himal & 2035 & 1997 \\
3 & Manaslu CA & High Mountain -High Himal & 1663 & 1998 \\
& Total & & 11327 & \\
\hline
\end{tabular}

About $18.33 \%$ of the total area of the country is managed under PAS.

(Royal Chitwan National Park and Sagarmatha National Park have been included in the world heritage list of UNESCO in 1984 and 1979 respectively. Koshi Tappu Wildlife reserve has been declared a Ramsar Site since 1987.

- Increase in number of endangered species Efforts of protective conservation have had significant impacts on the revival and survival of many endangered species. For example, rhino in Chitwan and Bardia, tiger and wild elephant in Chitwan, wild water buffalo in Koshi Tappu, swamp deer in Sukla Phanta, Ungulate in general in all the Terai parks, musk deer and Himalayan tahr in Langtang etc.

- Ensure watershed conservation and regulate fresh water Protected areas consisting of high mountainous regions are watersheds of the country's major river systems as they ensure fresh water supply to down stream people.

- Income generation Almost all PAS are major tourist destinations in Nepal, visited by about $50 \%$ of the total tourists visiting the country. Tourism has become a major source of income for PAS, which is as high as 87 to $92 \%$ of total revenue. ${ }^{2}$

\section{Major Issues}

Although the protective conservation approach, a fortress concept of wildlife management, has been successful in many protected areas of Nepal, some conflicts have occurred between park management and the local people due to various reasons. On the one hand, some species of wildlife threaten the life.and property of people in the surrounding areas, on the other hand habitat encroachments for resource exploitation, settlement and poaching are serious threats to the wildlife of some of the PAS. As a result, despite mounting efforts over the past two decades, threats to sustainable biodiversity conservation and management continuously exist in different forms and scale. The protective conservation approach (people exclusive model of conservation) seems insufficient to manage the PA system and conserve the biodiversity of Nepal owing to its fines and fences dependency. 


\section{Participatory Conservation Approach}

The philosophy of the participatory conservation approach is to integrate community development with natural resources management and promote the conservation of biodiversity and cultural heritage through the mobilization of local people. Since the mid nineteen eighties, it has been realized that striking a balance between both wildlife and human needs can ensure future conservation. ${ }^{3}$ To ensure community participation in biodiversity conservation, $\mathrm{Nepal} \mathrm{has} \mathrm{formulated} \mathrm{various} \mathrm{innovative}$ legal and policy frameworks.

Currently, Nepal is trying to balance the protective and participatory approach of conservation simultaneously. Various policies and programmes have been forwarded to incorporate the local needs and practices of PA management. For example, the Himalayan park regulation allows local people to collect fuelwood, fodder and litter for their domestic use and encourages rotational grazing in highland pastures. Similarly in the Terai, local fishermen are granted permission to collect fish for their living. The park also allows local people a regularized grass, thatched grass and fuelwood collection annually for a short period. Since the mid nineteen eighties, Nepal has initiated a new participatory biodiversity conservation approach through the establishment of conservation areas, joint people-park management activities, buffer zone programmes etc.

- Community Forestry: The community forestry programme is one of the most successful participatory resource conservation initiatives in Nepal. About 3.1 million ha (61\%) of Nepal's forest area consisting mostly of hills, is considered as potential community forests and the government has adopted a policy of handing over using rights of all accessible hill forests to local forest user groups (FUG). By 2000, about 0.773 million ha of state owned forest had been handed over to over ten thousand FUGs having above one million households as members. As community forestry programmes have been found to be successful in improving the condition of forests, it is seen as being instrumental in protecting the biodiversity of the mid-hilly region (500 to $3,500 \mathrm{~m}$ elevation) of the country.

- Park People Joint National Park Management Programme-A new park management approach: The Department of National Park and Wildlife Conservation (DNPWC) in collaboration with The Mountain Institute (TMI) initiated a new park management approach in the Makalu Barun Conservation Project (MBCP) in 1992 to examine and demonstrate managing parks with the help of the local people. This new approach has given emphasis to the dependence of local people on park resources for their subsistence. The resources are made available to them if such exploitations are consistent with the primary conservation objectives. The experience is encouraging and demonstrates that the park can be managed with the guardianship of local people, in contrary to the prevailing practice of strict 
protection by park personnel and the army. This can be seen in the Makalu Barun National Park and Conservation Area, which has been managed without the army.

- Buffer Zone Management Model: Buffer Zone (BZ) conservation is seen as a viable option to relieve conflict as well as anthropogenic pressure on PAS, by providing the people in adjoining areas with alternative livelihood options. The method is more of an integrated approach to conservation as it involves working closely with the local communities and PA staff. One of the biggest strengths of the concept is channeling back $35-50 \%$ of the protected areas revenue for developmental activities in the related buffer zone.

Since 1995, the BZ initiative has been adopted as a conservation strategy to mitigate conflicts, and increase the participation of local communities in biodiversity conservation. Since 1995, DNPWC has been implementing the Park People Programme (PPP) with the help of UNDP to conserve parks by forging a partnership between community organizations based on self-reliance. The PPP aims at enhancing the capacity of $\mathrm{BZ}$ communities and the PA staff to implement community based biodiversity conservation activities in the PAS of the country with the sole aim of conserving biodiversity by improving socio-economic conditions and natural resource bases in the buffer zones. So far, BZs of six national parks and three wildlife reserves have been declared. The major programmes of the projects are: poverty alleviation for conservation, policy supports in biodiversity conservation, institutional strengthening at local level, mainstreaming gender in conservation, piloting conservation activities at the grassroots, and networking and resource mobilization. These people-centered approaches to conservation empower people, and establish conservation in partnership with the local people.

- Conservation Area Management Model: In 1986, Nepal initiated a conservation area management model with the participation of local people in the Annapurna Himalaya region of western Nepal. This unique model is known as the Annapurna Conservation Area Project (ACAP). The ACAP is run under the aegis of the King Mahendra Trust for Nature Conservation (KMTNC). KMTNC is an autonomous, non-profit making and non-governmental organization dedicated to the conservation, management, sustainable utilization and promotion of nature and natural resources. The KMTNC has taken a people oriented approach to promoting nature conservation by meeting the current economic and social needs. The KMTNC operates under a Governing Board of trustees, comprising of prominent persons from diverse fields including non-Nepalese members. It has been successfully implemented with an innovative protected area management system for conservation, and use of natural resources by promoting rural development through the involvement of the local people.

The Annapurna Conservation Area Project (ACAP) began its conservation initiatives as a pilot project in 1986 in the Ghandruk village. During the last 15 
years, the ACAP has evolved from being an experimental integrated and development project (ICNP) model to become a successful conservation model which incorporates sustainable development to maintain biodiversity.

\section{Principles of ACAP}

ACAP was the first initiative in Nepal's protected area management where people were recognized as partners in conservation and stewards of natural resources. Therefore, empowerment of local residents to enjoy the rights and responsibilities for managing forest resources was fundamental, as participatory land management programmes do not weaken land ownership but promote rights to use the productivity of the land in exchange for protection. To achieve this goal, the ACAP has adapted three guiding principles.

Peoples participation: The ACAP involves the local residents in the planning, decision-making and implementing processes and delegates responsibilities to them to manage the Conservation Area. Active participation of people in all stages of project planning is solicited.

Catalyst or matchmakers: The ACAP acts as a catalyst to meet the needs of some 100,000 inhabitants and to manage over 48,000 annual visitors (foreign trekkers with their Nepalese support staff). Therefore, the project acts as a bridge between various international and national agencies, and community needs to obtain appropriate expertise and resources.

Sustainability: As ACAP's activities are based on sustainability, only projects and programmes which the people can manage even after the external support is withdrawn are implemented. Encouraging people to participate and making them invest in cash or kind in conservation and development have ensured sustainability.

\section{ACAP's Objectives}

The ACAP in Nepal attempts to address the problem of conserving the fragile mountain environment while at the same time improving the economic condition of the inhabitants of that environment. Recognizing that protection of habitats and the maintenance of biodiversity cannot be achieved without the support of the inhabitants, ACAP has three primary long-term goals:

i) To conserve natural resources,

ii) To bring about sustainable socio-economic development, and

iii) To develop tourism in such a way that it has a minimum negative environmental impact i.e. eco-friendly tourism. 


\section{Programmes}

The ACAP has developed and implemented seven major programmes with a view to conserving the local biodiversity, they are (1) natural resource conservation 2) alternative energy development, 3) conservation education extension, 4) community development, 5) tourism management, 6) heritage conservation, and 7) agriculture development.

The main objectives are to promote community development programmes, conserve the cultural heritage and natural environments, and to manage natural resources on a sustainable basis. ACAP has adopted a holistic and integrated approach which considers the people as an active partner of the conservation programmes.

Driven by the encouraging success of ACAP, this model was later adopted to the Makalu Barun Conservation Area, the Kanchenjunga Conservation Area, and the Manaslu Conservation Area.

\section{Landscape Conservation Initiatives in Nepal}

Despite the encouraging achievements in the field of conservation and sustainable use of natural resources, the country's globally significant biodiversity has not been found to be safe from degradation. The obvious reasons being; i) some of the PAs are too small for long term viability of flagship and other migratory species, ii) substantial biodiversity rich areas lie outside the PAS, and iii) all the representative habitat types of the country have not been covered by the existing PAS. This calls for the holistic and landscape level approach for conservation and sustainable use of biodiversity.

Several initiatives to adopt the landscape approach have already been started in the country. These include the Conservation Area Model (ACAP; MCAP and KCAP), HMG/UNDP's Park People Programme, HMG/WWF's Terai Arc Programme, KMTNC's Rhino-Tiger Landscape Project in Chitwan, HMG/UNDP's the Biodiversity Landscape Projects etc.

\section{Main Objectives}

Its main objective is to integrate conservation with natural resource management in PAs and community development in productive areas.

The Terai Arc: A Landscape Approach in Conservation. The Terai Arc is a vision and dream of the World Wildlife Fund (WWF) of linking eleven Trans-border PAs and forests spread across about 49,000 sq. km in Nepal and India through the biological corridors. The ambitious two fold goals of the project are to reconnect the 
existing PAs of the two countries and to ensure management of the landscape as a conservation unit through community mobilization and cooperation of different stakeholders for effective land use practices, thereby facilitating seasonal wildlife movement and genetic dispersal between populations. Creation of economic opportunities for local people is a secondary objective.

\section{Eco-region Based Conservation in the Eastern Himalaya}

The eastern Himalaya eco-region of WWF includes parts of Nepal, India, Bhutan, China and Myanmar.

\section{Goals}

The main goals are to conserve representative facets of biodiversity within the habitat areas, large enough to support the natural ecological and evolutionary processes that maintain it. This long-term goal will be achieved by linking core-protected areas within the large conservation landscapes, involving indigenous people in conservation actions, and promoting trans-border cooperation among the range states.

\section{Nepal's Biodiversity Landscape Project}

Goals to conserve globally significant biodiversity at three priority landscape complexes of Nepal viz. Bardia-Suklaphanta complex, Makalu-Barun complex and Kanchenjunga complex, by strengthening the management of priority PAs and working with surrounding local communities, to ensure that they actively participate and benefit from conservation.

The major focus of participatory biodiversity conservation of Nepal is to integrate conservation efforts into social, economical and cultural issues and agenda, within and outside PAs that secure long-term sustainability of biodiversity conservation. Thus, Nepal's conservation policies and programmes have been evolved from species conservation to participatory landscape conservation. The landscape conservation approach is still in its initial stage and needs further practical experiences.

\section{Conclusion}

The indigenous conservation approaches believed to be sustainable, holistic and effective, were eroded and replaced by the people exclusive model of parks which were highly successful in limited areas because it ignored people's participation and relied mainly on park staff and army for its protection. Conservation of natural resources at the cost of people's livelihood is neither ethically justifiable nor passable in the long run. A balance between these two approaches of conservation identified 
in Nepal, is the participatory conservation approach; based on the active involvement of the local people, and development of common understanding of our biodiversity conservation. This has resulted in a situation where there has been a move from conflict to co-existence.

\section{Recommendations}

- Preserve indigenous systems of resource management.

- Encourage peoples participation in nature conservation.

- Promote communication, cooperation and good understanding between the concerned authority and the local people.

- Establish new PAs including those habitats which are not represented by the existing PAs.

- Revive the indigenous techniques of nature conservation, which are still valuable and practical.

\section{References}

1 Basent K. (1992). Conservation practices in Nepal: Past and Present. Ambio, 21(6).

2 Budhathoki P. (2001). Participatory Biodiversity Conservation in Nepal. In: (Eds. M .K. Balla, S. Rayamajhi and N.M.B. Pradhan). Kathmandu: FONAREM

3 DNPWC/PPP/UNDP.(1999). Park People bulletin. DNPWC/PPP/UNDP

4 Gurung O.(1994). Historical dynamics of resource degradations in the Nepal Himalayas. In: Anthropology of Nepal: people, problems and processes. (Eds. Allen). Mandela Book Point, Kathmandu

5 IUCN. (1995). World Directory of National Parks and Other Protected Areas. Gland: IUCN

6 Regmi M.C.(1971). A study of Nepali Economic History. New Delhi: Oxford University Press

7 Shah K.B. (2001). Prakritik shrot sanrachhyan ka ie anautha tarikaharu (unique methods of natural resource conservation: in Nepali) SADHANA, A Nepali monthly magazine, Kathmandu, Nepal. 